\title{
Pendampingan pada Keluarga dengan Anak Berisiko Stunting di Kelurahan Muktiharjo Kidul, Semarang
}

\author{
Dyah Wiji Puspita Sari ${ }^{*}$, Maya Dwi Yustini $^{2}$, Apriliani Yulianti Wuriningsih ${ }^{3}$, \\ Kholidah $^{4}$, Nopi Nur Khasanah ${ }^{5}$,Muh. Abdurrouff ${ }^{6}$, Retno Setyawati $^{7}$ (iD \\ 1,2,3,4,5,6,7 Fakultas Ilmu Keperawatan, Universitas Islam Sultan Agung, Semarang, Indonesia \\ *Corresponding author: Puspita898@gmail.com
}

\begin{abstract}
Abstrak
Stunting telah menjadi ancaman permasalahan gizi dunia yang perlu segera ditangani. Indonesia merupakan negara yang memiliki jumlah anak balita pendek terbesar dibandingkan dengan negara Malaysia, Thailand, serta Vietnam. Pengabdian kepada masyarakat ini bertujuan untuk mengatasi ancaman tersebut dengan mengajarkan cara mengelola bayi usia di bawah dua tahun yang berisiko menjadi tidak berisiko stunting. Metode yang digunakan dalam pengabdian masyarakat ini adalah pendampingan dengan memberikan berbagai intervensi keperawatan pada keluarga dengan anak berisiko stunting. Metode di atas diimplementasikan dalam 3 (tiga) tahapan yaitu (1) sosialisasi, (2) pelaksanaan kegiatan, serta (3) monitoring dan evaluasi. Hasil pelaksanaan kegiatan ini yaitu pendampingan oleh tenaga kesehatan professional memberikan peran yang besar pada pencegahan risiko stunting. Kesimpulan dalam kegiatan ini yaitu pendampingan pada keluarga berisiko stunting menjadi strategi yang efektif untuk memberdayakan masyarakat dalam rangka meningkatkan kesiapan anggota keluarga untuk mencegah resiko stunting. Kegiatan ini merupakan salah satu solusi unggulan yang menyentuh secara langsung masyarakat dalam pencegahan stunting.
\end{abstract}

Kata Kunci: Pendampingan, Keluarga Berisiko Stunting, Pengabdian Masyarakat

\section{Abstract}

Stunting has become a global nutritional problem that needs to be addressed immediately. Indonesia is a country that has the largest number of short toddlers compared to Malaysia, Thailand and Vietnam. This community service aims to overcome this threat by being taught about how to manage infants under the age of two who are at risk of becoming not at risk of stunting. The method used in this community service is assistance by providing various nursing interventions to families with children at risk of stunting. The above method is implemented in 3 (three) stages, namely (1) socialization, (2) implementation of activities and (3) monitoring and evaluation. The result of the implementation of this activity is that assistance by professional health workers plays a major role in preventing the risk of stunting. The conclusion in this activity is that assistance to families at risk of stunting is an effective strategy to empower the community in order to increase the readiness of family members to prevent stunting risk and one of the leading solutions that directly touch the community in stunting prevention.

Keywords: Mentoring, Families at Risk of Stunting, Community Service

\section{PENDAHULUAN}

Menurut Pusat Data dan Informasi Kementerian Kesehatan RI (2018) angka kejadian stunting di dunia mencapai $23,2 \%$ pada tahun 2015. Terdapat 83,6 juta balita yang mengalami stunting di Asia, proporsi tertinggi terdapat pada Asia Selatan yaitu 58,7\% dan proporsi terendah pada Asia Tengah 0,9\% (Aridiyah et al., 2015). Menurut World Association Organization (2018), Indonesia adalah negara yang berasal dari Asia Tenggara, dalam angka kejadian stunting sendiri Indonesia meduduki nomer tiga dengan proporsi tertinggi di Asia Tenggara yaitu pada tahun 2015-2017 mencapai 36,4\% (Saputri \& Tumangger, 2019; Tampubolon et al., 2020).

$\begin{array}{ll}\text { History: } & \\ \text { Received } & \text { : September 12, } 2021 \\ \text { Revised } & \text { : September 16, } 2021 \\ \text { Accepted } & \text { : November 03, 2021 } \\ \text { Published } & \text { : November } 25,2021\end{array}$


Negara berkembang seperti Indonesia memiliki masalah yang kompleks, yaitu mulai dari angka kemiskinan yang tinggi hingga angka gizi kurang yang tinggi (Annur, 2013; Astuti, 2016). Status gizi balita pada hasil utama Riset Kesehatan Dasar (Riskesdas) tahun 2018 menunjukkan bahwa balita yang mengalami gizi kurang dan buruk mencapai angka 17,7\%; sedangkan balita sangat pendek dan pendek mencapai angka 30,8\% (BPPK, 2018). Pada baduta, secara keseluruhan terdapat 18 provinsi dengan prevalensi tinggi $(30 \%-<40 \%)$ yang memiliki masalah status gizi sangat pendek dan pendek, termasuk provinsi Jawa Tengah (Adriani \& Kartika, 2013; Miko \& Al-Rahmad, 2017). Menurut survey data Pemantauan Status Gizi atau PSG (2018) menunjukkan bahwa status gizi balita jawa tengah tahun 2017 pada kategori balita gizi kurang sebanyak 17\%, balita pendek sebanyak 28,5\%, dan balita kurus sebanyak 9,3\% (Juniar et al., 2022; Yuwanti et al., 2021).

Berbagai bukti ilmiah dari lembaga riset gizi dan kesehatan terbaik di dunia menunjukkan bahwa faktor penyebab terpenting stunting adalah lingkungan hidup sejak konsepsi sampai anak usia 2 tahun yang dapat diubah dan diperbaiki dengan fokus pada masa 1000 HPK (Barker \& Thornburg, 2013; Sari et al., 2021), bukan karena faktor utama yaitu faktor genetik seperti anggapan masyarakat pada umumnya (Adliyani, 2015; Wuriningsih, 2020). Masalah stunting akan segera teratasi dengan baik apabila ada solusi yag efektif dalam perbaikan gizi dan pelayanan kesehatan yang memadai pada masa-masa 1000 HPK. Pemenuhan gizi pada kelompok 1000 HPK merupakan prioritas utama dalam solusi untuk mengurangi jumlah anak pendek di generasi yang akan datang dan seterusnya (Ahmed et al., 2001; Barker \& Thornburg, 2013).

Data yang didapat pada studi pendahuluan melalui hasil screening tim pengabdi di wilayah mitra Puskesmas Pembantu Muktiharjo Kidul didapatkan data bahwa terdapat 25 bayi yang berisiko stunting dengan kategori rendah dan sedang dengan memiliki hasil skor $<-2$ SD. Berdasarkan data ini, dapat dikatakan bahwa prevelensi anak stunting di wilayah binaan Puskesmas Pembantu Muktiharjo Kidul atau di Kelurahan Muktiharjo Kidul masih tinggi (Imtihanatun, 2013). Pemilihan Puskesmas Pembantu Muktiharjo Kidul sebagai mitra disebabkan oleh tingginya anak yang berisiko stunting. Pada masa pandemi banyak keluarga yang tidak mau mengunjungi pusat layanan kesehatan untuk mendapatkan layanan pemantuan tumbuh kembang anak yang berisiko stunting (Adriana, 2011). Banyak baduta berisiko stunting yang kurang optimal dalam mendapatkan layanan pencegahan stunting. Pendampingan pada keluarga berisiko stunting melibatan anggota keluarga yang memberikan pengasuhan kepada anak. Keluarga tersebut akan diajarkan cara mengelola bayi usia di bawah dua tahun yang berisio menjadi tidak berisiko stunting.

\section{METODE}

Metode yang digunakan dalam pengabdian masyarakat ini adalah pendampingan dengan memberikan berbagai intervensi keperawatan. Awal mulanya tenaga kesehatan melakukan screening pada baduta binaan Puskesmas Muktiharjo Kidul yang berisiko stunting. Pada baduta yang dinyatakan berisiko stunting selanjutnya dilakukan pemantauan tumbuh kembangnya (Sulistyawati, 2014). Pemantuan tumbuh kembang ini ditambahkan dengan intervensi pijat bayi yang berfungsi untuk meningkatkan berat badan anak, baby spa untuk melatih motorik anak, serta pemberian MPASI untuk meningkatkan status gizi baduta, serta edukasi tentang ASIP (Mufida et al., 2015; Nova \& Afriyanti, 2018; Trihono et al., 2013). Selain itu. tim pengabdi juga memberikan pendidikan kesehatan sebagai bekal bagi keluarga untuk memiliki kemandirian dalam mencegah anak yang berisiko stunting.

Selanjutnya, metode di atas diimplementasikan dalam 3 (tiga) tahapan yaitu (1) sosialisasi, (2) pelaksanaan kegiatan, serta (3) monitoring dan evaluasi. Penggunaan tahapan ini merupakan sebuah metode yang efektif digunakan untuk memberikan peningkatan 
pengetahuan dan ketrampilan para pendamping atau pengasuh baduta yang berisiko stunting. Efektivitas tahapan ini akan mendukung keberhasilan program yang telah ditetapkan oleh prodi. Pada tahap sosialisasi, tim pengabdi memberikan paparan dengan menjelaskan pentingnya berbagai intervensi keperawatan yang harus dilakukan untuk pencegahan risko stunting pada anak (Ekayanthi \& Suryani, 2019). Tahap pelaksanaan kegiatan dibagi menjadi dua yaitu kegiatan pemberian pendampingan pada keluarga anak yang berisiko stunting dan intervensi keperawatan secara langsung pada anak yang berisiko stunting. Keluarga dengan anak berisiko stunting yang terlibat sejumlah 23 orang dan baduta yang berisiko stunting juga sejumlah 23 anak. Pada tahapan ini perawat mengajarkan kepada para keluarga pendamping anak berisiko stunting melalui metode contoh dengan memberikan intervensi keperawatan secara langsung pada anak yang berisiko stunting mulai dari screening atau deteksi dini risiko stunting, pemantauan tumbuh kembang anak, baby spa, baby message, cara menyimpan ASIP, dan pemberian MPASI. Dari semua intervensi ini diharapkan keluarga mengalami peningkatan pemahaman dalam pencegahan stunting dan anak mencapai tumbuh kembang dengan optimal.

Pada tahap monitoring dan evaluasi dilakukan pemantauan terhadap hasil tumbuh kembang anak dengan resiko stunting setelah diberikan berbagai intervensi keperawatan oleh tim pengabdi. Tahap monitoring dan evaluasi dilaksanakan setiap bulan sekali. Apabila dalam proses pelaksanaan kegiatan ditemukan kendala, tim pengabdian memberikan pembinaan dan penguatan terhadap masalah yang ditemukan. Proses pendampingan yang dilakukan oleh tenaga kesehatan profesional dilaksanakan melalui kunjungan rumah. Pelaksanaan kegiatan ini dilaksanakan dari bulan Maret hingga November 2021. Teknik pengumpulan data dilakukan dengan menggunakan lembar observasi. Teknik analisis data yang digunakan dalam pelaksanaan kegiatan pengabdian masyarakat ini adalah distribusi frekuensi.

\section{HASIL DAN PEMBAHASAN}

\section{Hasil \\ Kontribusi Mitra}

Kegiatan pengabdian masyarakat melalui pendampingan pada keluarga berisiko stunting telah dilaksanakan melalui tahapan sosialisasi, pelaksanaan kegiatan, serta monitoring dan evaluasi. Pada tahapan sosialisasi memberikan hasil bahwa para keluarga pendamping anak yang berisiko stunting memahami, mempunyai pola pikir, dan mempunyai komitmen pada perannya dalam mencegah anaknya berisiko stunting. Kegiatan sosialisasi ini menjadi tahapan yang sangat penting untuk memberikan pemahaman tentang arti pentingnya pencegahan baduta yang berisiko stunting di masyarakat. Proses pelaksanaan sosialisasi ditunjukkan pada Gambar 1.

Pada tahap pelaksanaan, sebelumnya keluarga pendamping anak yang berisiko stunting diberikan pre test tentang berbagai pengetahuan yang berkaitan dengan stunting, seperti cara melakukan skrining atau deteksi dini pada baduta yang beresiko stunting, cara membuat MPASI, cara pijat bayi, cara baby spa, cara menyimpan ASIP, dan lain-lain. Pada anak juga dilakukan skrining risiko stunting. Kegiatan dilanjutkan dengan pemberian materi dengan contoh intervensi secara langsung kepada para baduta. Setelah pemberian materi, maka kegiatan ini diakhiri dengan post-test. Pelaksanaan pre test diharapkan dapat dijadikan tolok ukur untuk melihat risiko stunting baduta, kemampuan keluarga pendamping dengan anak berisiko stunting untuk melakukan skrining risiko stunting, serta melihat pemahamannya tentang berbagai intervensi keperawatan yang telah diberikan (Sari, 2020). Hasil pre test menunjukkan terdapat 23 baduta berisiko stunting dan hampir seluruh keluarga pendamping belum memahami secara benar tentang pencegahan baduta berisiko stunting. 
Setelah dilaksanakan proses pendampingan oleh TIM pengabdi, maka kemampuan keluarga pendamping tentang pencegahan risiko stunting mengalami peningkatan yang signifikan serta jumlah baduta yang berisiko stunting mengalami penurunan menjadi tidak berisiko. Seluruh kegiatan pendampingan ini dilakukan dengan metode pelatihan, role play, pemberian pendidikan kesehatan, penyuluhan dan intervensi secara langsung ke baduta berisiko stunting. Pelaksanakan kegiatan disajikan pada Gambar 2, Gambar 3, dan Gambar 4.

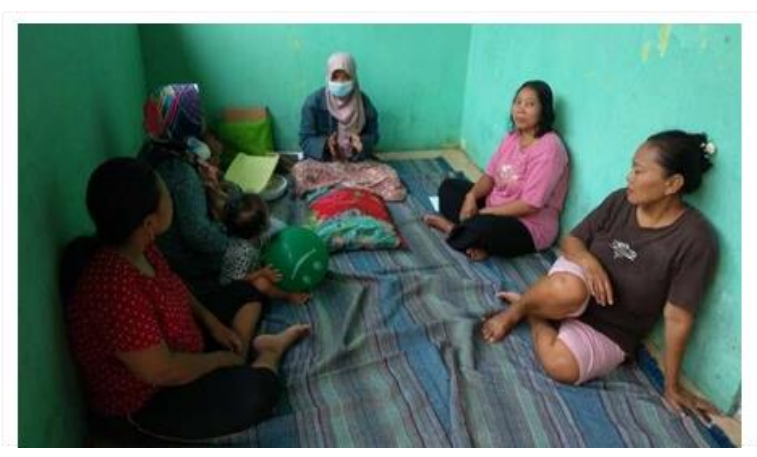

Gambar 1. Pelaksanaan Sosialisasi

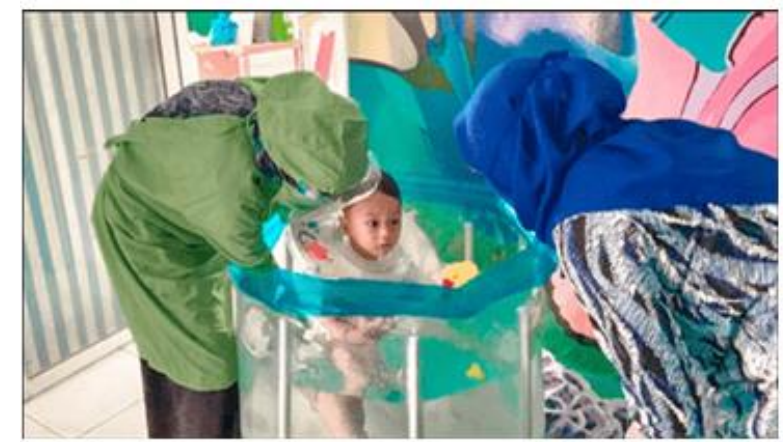

Gambar 2. Baby Spa

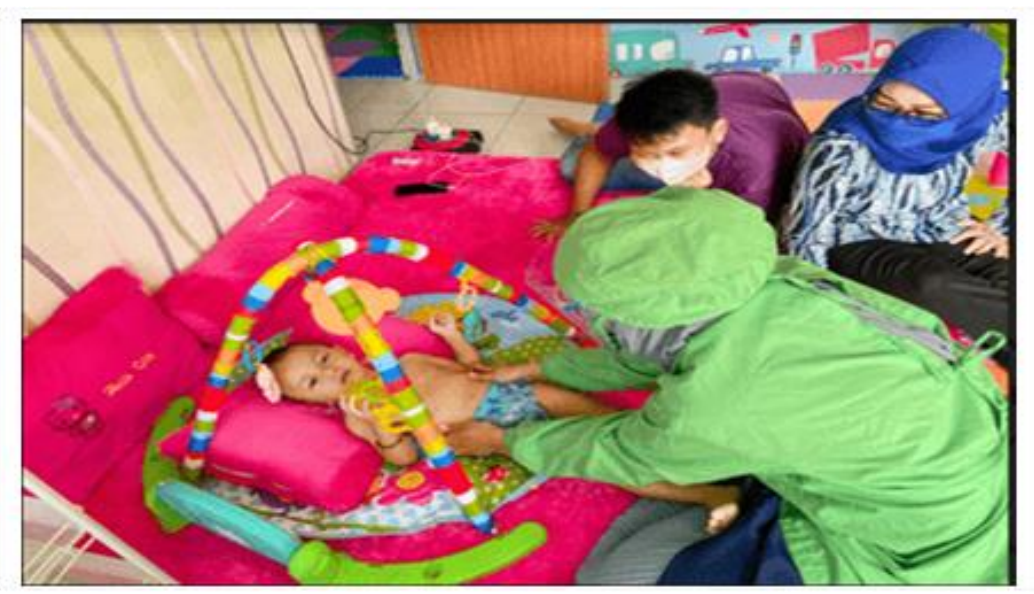

Gambar 3. Baby massage
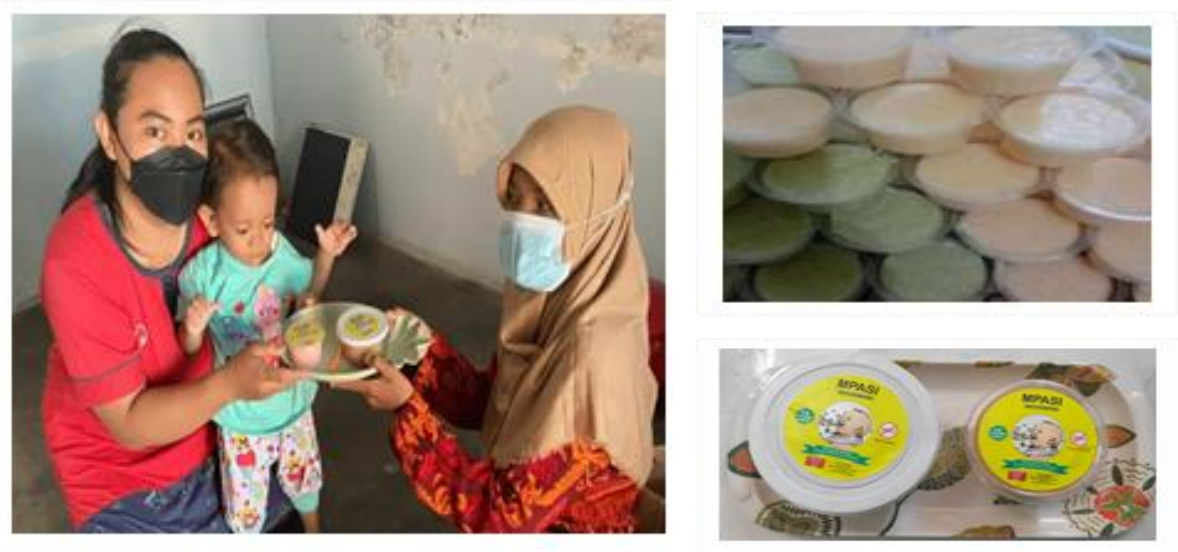

Gambar 4. Pemberian MPASI

Pemberian pendidikan kesehatan dan penyuluhan merupakan suatu metode yang dilaksanakan untuk menyampaikan informasi kepada masyarakat, kelompok, atau individu 
dengan tujuan kelompok atau individu tersebut mendapatkan pengetahuan tentang perawatan kesehatan yang lebih baik (Hapitria \& Padmawati, 2017; Hidayati, 2015). Hal ini dikuatkan oleh penelitian yang menyatakan bahwa informasi akan berpengaruh terhadap pengetahuan seseorang (Ngatu \& Rochmawati, 2018). Kegiatan penguluhan disajikan pada Gambar 5.

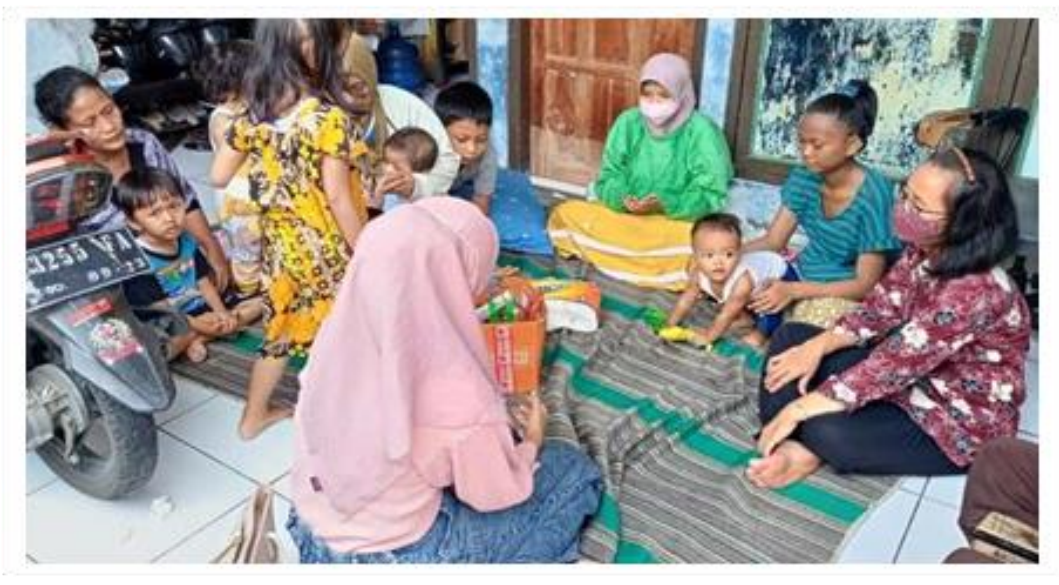

Gambar 5. Pendampingan melalui penyuluhan dan pendidikan kesehatan tentang cara pencegahan stunting

Tahapan monitoring dan evaluasi dilaksanakan setiap bulan sekali dengan cara dilakukan pengukuran terhadap perkembangan tinggi badan, berat badan dan tumbuh kembang anak untuk mengetahui penurunan risiko stunting. Monitoring dan evaluasi merupakan sebuah proses yang dilakukan secara kontinyu mulai dari pengumpulan data hingga progress yang dicapai pada program kerja tersebut hingga dampak dan efek dari adanya program tersebut (Faried, 2018; Normina, 2016). Kegiatan monitoring dan evaluasi diperlukan untuk melihat tingkat keberhasilan dan ketercapaian tujuan dan manfaat programprogram pembangunan (Muktiali, 2009; Tristianto, 2022). Dokumentasi kegiatan monitoring dan evaluasi disajikan pada Gambar 6.
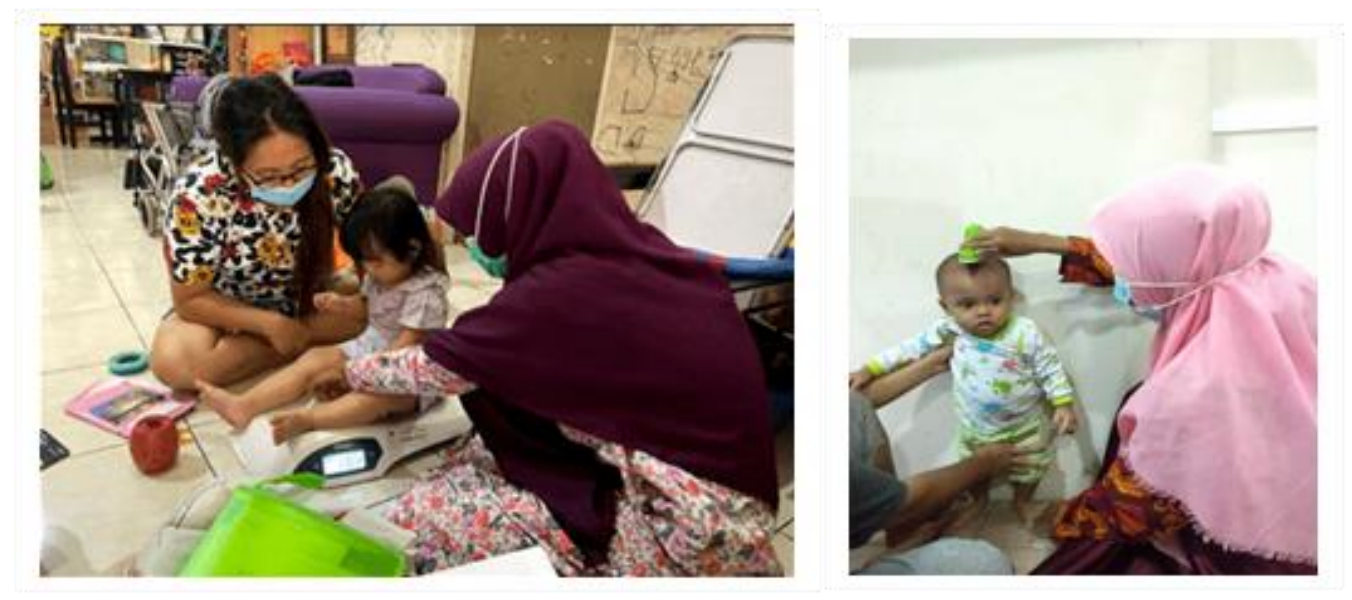

Gambar 6. Kegiatan Monev

Hasil monitoring evaluasi menunjukkan hasil analisis data bahwa terdapat perbedaan risiko stunting sebelum dan setelah mengikuti program pengabdian masyarakat melalui pendampingan pada keluarga berisiko stunting. Pada kondisi awal ditemukan klien yang memiliki risiko tinggi stunting dari 7 (28\%) menjadi 1 (34\%), klien dengan risiko rendah stunting sejumlah $12(48 \%)$ berkurang menjadi $3(12 \%)$ dan klien yang tidak berisiko 
stunting sejumlah 6 (24\%) bertambah menjadi 21 (84\%). Keunggulan program pengabdian masyarakat pendampingan pada keluarga berisiko stunting yaitu menjadi salah satu terobosan baru dalam penentuan strategi yang efektif dan terintegrasi, berbasis masyarakat untuk menurunkan resiko stunting. Pada Pelaksanaan kegiatan pengabdian ini berjalan dengan lancar.

\section{SIMPULAN DAN SARAN}

Pengabdian masyarakat melalui pendampingan pada keluarga berisiko stunting di Kelurahan Muktiharjo Kidul Semarang memberikan peran yang besar pada pemantauan pencegahan baduta yang berisiko stunting serta menjadi strategi yang efektif untuk memberdayakan masyarakat dalam rangka meningkatkan kesiapan anggota keluarga, khususnya para pengasuh anak untuk mencegah risiko stunting. Rekomendasi untuk kegiatan pengabdian masyarakat selanjutnya adalah mengembangakan program pendampingan ke masyarakat secara luas yang memiliki anak yang berisiko stunting. Program kegiatan ini masih berada dalam lingkup yang kecil, tetapi telah memberikan dampak yang cukup baik inidalam menurunkan resiko stunting. Oleh karena itu, diharapkan kegiatan seperti ini menjadi inisiasi awal bagi pusat layanan kesehatan masyarakat untuk melaksankan program kesehatan unggulan pencegahan stunting.

\section{UCAPAN TERIMAKASIH}

Ucapan terima kasih disampaikan kepada Kementrian Pendidikan, Kebudayaan, Riset, dan Teknologi yang telah memberikan biaya pengabdian masyarakat tahun penerimaan 2019 . Terimakasih kepada Lembaga Penelitian dan Pengabdian Masyarakat Unissula serta Puskesmas Telogosari Kulon yang telah memfasilitasi dan mendukung pelaksanaan pengabdian masyarakat ini hingga selesai dengan baik.

\section{DAFTAR RUJUKAN}

Adliyani, Z. O. N. (2015). Pengaruh Perilaku Individu terhadap Hidup Sehat. Jurnal Majority, $\quad 4(7)$,

109-114. http://juke.kedokteran.unila.ac.id/index.php/majority/article/view/1458.

Adriana, D. (2011). Tumbuh Kembang dan Therapy Bermain pada Anak. Salemba Medika.

Adriani, M., \& Kartika, V. (2013). Pola Asuh Makan pada Balita dengan Status Gizi Kurang di Jawa Timur, Jawa Tengah dan Kalimantan Tengah, Tahun 2011. Buletin Penelitian Sistem Kesehatan, 16(2), 20847. https://www.neliti.com/publications/20847/polaasuh-makan-pada-balita-dengan-status-gizi-kurang-di-jawa-timur-jawa-tengah.

Ahmed, F., Rahman Khan, M., \& Jackson, A. A. (2001). 'Concomitant Supplemental Vitamin A Enhances the Response to Weekly Supplemental Iron and Folic Acid in Anemic Teenagers in Urban Bangladesh.' American Journal of Clinical Nutrition, 74(1), 108-115. https://academic.oup.com/ajcn/article-abstract/74/1/108/4739650.

Annur, R. A. (2013). Faktor-Faktor yang Memengaruhi Kemiskinan di Kecamatan Jekulo dan Mejobo Kabupaten Kudus Tahun 2013. Economics Development Analysis Journal, 2(4).

Aridiyah, F. O., Rohmawati, N., \& Ririanty, M. (2015). Faktor-Faktor yang Memengaruhi Kejadian Stunting pada Anak Balita di Wilayah Pedesaan dan Perkotaan. Pustaka Kesehatan, $3(1)$, 163-170. http://jurnal.unej.ac.id/index.php/JPK/article/download/2520/2029.

Astuti, D. K. (2016). Hubungan Karakteristik Ibu dan Pola Asuh Gizi dengan Kejadian 
Balita (Universitas Muhammadiyah Surakarta). Universitas Muhammadiyah Surakarta. http://eprints.ums.ac.id/42620/\%0A\%0A.

Barker, D. J. P., \& Thornburg, K. L. (2013). 'Placental Programming of Chronic Diseases, Cancer and Lifespan: A Review.' Placenta, 34(10), 841-845. https://doi.org/10.1016/j.placenta.2013.07.063.

BPPK. (2018). Hasil utama riskesdas 2018.

Ekayanthi, N. W. D., \& Suryani, P. (2019). Edukasi Gizi pada Ibu Hamil Mencegah Stunting pada Kelas Ibu Hamil. Jurnal Kesehatan, 10(3), 312-319. https://ejurnal.poltekkestjk.ac.id/index.php/JK/article/view/1389.

Faried, A. I. (2018). Keterhubungan Pola Pengambilan Keputusan Efektif, Struktur dan Budaya Organisasi di Universitas Pembangunan Panca Budi Medan. JUMANT, 8(2), 1-12. https://journal.pancabudi.ac.id/index.php/JUMANT/article/view/108.

Papitria, P., \& Padmawati, R. (2017). Efektivitas Pendidikan Kesehatan melalui Multimedia dan Tatap Muka terhadap Pengetahuan dan Sikap Ibu Hamil tentang ASI dan Menyusui. Care: Jurnal Ilmiah Ilmu Kesehatan, 5(2), 156-167. https://jurnal.unitri.ac.id/index.php/care/article/view/535.

Hidayati, E. (2015). Pengetahuan dan Stigma Masyarakat terhadap TBC setelah Diberikan Pendidikan Kesehatan Pencegahan dan Penularan. Jurnal Keperawatan Soedirman, 10(2), 76-82. http://jks.fikes.unsoed.ac.id/index.php/jks/article/view/602.

Imtihanatun, N. (2013). Faktor Risiko Balita Stunting Usia 12-36 Bulan di Puskesmas Dasan Agung, Mataram, Provinsi Nusa Tenggara Barat. Public Health and Preventive Medicine Archive, 1(1). https://www.neliti.com/publications/21448/faktor-risikobalita-stunting-usia-12-36-bulan-di-puskesmas-dasan-agung-mataram.

Juniar, M. K., Paramesti, S. I., Wulandari, N. I., Rahayu, F., Syafatulloh, A. I., \& Ilmiselri, S. A. (2022). Upaya Pengentasan Masalah Stunting Melalui Pemberdayaan Masyarakat di Desa Pamijen Kecamatan Sokaraja. Jurnal of Community Health Development, 3(1), 63-72. http://jos.unsoed.ac.id/index.php/jchd/article/view/5030.

Miko, A., \& Al-Rahmad, A. H. (2017). Hubungan Berat dan Tinggi Badan Orang Tua dengan Status Gizi Balita di Kabupaten Aceh Besar. Gizi Indonesia, 40(1), 21-34. http://www.ejournal.persagi.org/index.php/Gizi_Indon/article/view/222.

Mufida, L., Widyaningsih, T. D., \& Maligan, J. M. (2015). Prinsip Dasar MPASI untuk Bayi Usia 6-24 Bulan: Kajian Pustaka. Jurnal Pangan Dan Agroindustri, 3(4), 1646-1651. https://jpa.ub.ac.id/index.php/jpa/article/view/290.

Muktiali, M. (2009). Penyusunan Instrumen Monitoring dan Evaluasi Manfaat Program Pembangunan di Kota Semarang. Jurnal Riptek, 3(2), 11-20. https://bappeda.semarangkota.go.id/uploaded/publikasi/Penyusunan_Instrumen_Moni toring_Dan_Evaluasi_Manfaat_Program_Pembangunan_Di_Kota_Semarang__M._MUKTIALI.pdf.

Ngatu, E. R., \& Rochmawati, L. (2018). Hubungan Pengetahuan tentang Anemia pada Remaja dengan Pemenuhan Kebutuhan Zat Besi pada Siswi SMKN 4 Yogyakarta. Jurnal Kebidanan Indonesia, 6(1). http://jurnal.stikesmus.ac.id/index.php/JKebIn/article/view/98.

Normina, N. (2016). Partisipasi masyarakat dalam pendidikan. Ittihad, 14(26). http://jurnal.uin-antasari.ac.id/index.php/ittihad/article/view/874.

Nova, M., \& Afriyanti, O. (2018). Hubungan bert badan, ASI eksklusif, MP-ASI dan asupan energi dengan stunting pada balita usia 24-59 bulan di Puskesmas Lubuk Buaya. Jurnal Kesehatan Perintis, http://www.jurnal.stikesperintis.ac.id/index.php/JKP/article/view/92.

Saputri, R. A., \& Tumangger, J. (2019). Hulu-Hilir Penanggulangan Stunting di Indonesia. $\begin{array}{lllll}\text { Journal of } & \text { Political } & \text { Issues, } & 1(1), & \text { 1-9. }\end{array}$ 
http://www.jpi.ubb.ac.id/index.php/JPI/article/view/2.

Sari, D. W. P. (2020). Kelompok Pendamping Makanan Pendamping ASI (KP-MPASI) di Rumah Sehat Anti Stunting (RS-AS). International Journal of Community Service Learning, $4(1)$, 44-51. https://ejournal.undiksha.ac.id/index.php/IJCSL/article/view/24168.

Sari, D. W. P., Wuriningsih, A. Y., Khasanah, N. N., \& Najihah, N. (2021). Peran Kader Peduli Stunting Meningkatkan Optimalisasi Penurunan Risiko Stunting. Jurnal Penelitian Dan Pemikiran Ilmiah Keperawatan, 7(1), 45-52. https://scholar.archive.org/work/rgptpfxdtvdm5kanrm35k2g5se/access/wayback/http:/ /jurnal.unissula.ac.id/index.php/jnm/article/download/17424/pdf.

Sulistyawati, A. (2014). Deteksi Tumbuh Kembang Anak. Salemba Medika.

Tampubolon, M. T., Fadilah, M., \& Roflin, E. (2020). Model Pengendalian Faktor Risiko Stunting pada Anak Balita Ditinjau dari Program STBM (Doctoral dissertation, Sriwijaya University). Universitas Sriwijaya.

Trihono, P. P., Djer, M. M., Sjakti, H. A., Hendrarto, T. W., \& Prawitasari, T. (2013). Best Practices in Pediatrics. Ikatan Dokter Anak Indonesia cabang DKI Jakarta. https://fk.ui.ac.id/wp-content/uploads/2016/01/Buku-PKB-IDAI-Jaya-X.pdf.

Tristianto, C. (2022). Penggunaan Metode Waterfall untuk Pengembangan Sistem Monitoring dan Evaluasi Pembangunan Pedesaan. Jurnal ESIT (E-Bisnis, Sistem Informasi, Teknologi Informasi), http://openjournal.unpam.ac.id/index.php/ESIT/article/view/18174.

Wuriningsih, A. Y. (2020). Rumah Sehat Anti Stunting Generasi Cerdas, Anti Stunting. In Unissula Nursing Conference Call for Paper \& National Conference, 2(1). http://lppm-unissula.com/jurnal.unissula.ac.id/index.php/unc/article/view/15454.

Yuwanti, Y., Mulyaningrum, F. M., \& Susanti, M. M. (2021). Faktor-Faktor yang Memengaruhi Stunting pada Balita di Kabupaten Grobogan. Jurnal Keperawatan Dan Kesehatan Masyarakat Cendekia Utama, 10(1), 74-84. http://www.jurnal.stikescendekiautamakudus.ac.id/index.php/stikes/article/view/704. 